\title{
New Titanium(IV) and Vanadium(IV) Haloalkoxides: Synthetic Route and Structural Characterisation
}

\author{
Giovana G. Nunes ${ }^{a}$, Dayane M. Reis ${ }^{a}$, Pedro H. C. Camargo ${ }^{a}$, Peter B. Hitchcock, \\ Manfredo Hörner, Robson M. Matos ${ }^{c}$, Antonio S. Mangrich ${ }^{a}$, Eduardo L. de Sá ${ }^{a}$, G. Jeffery Leigh ${ }^{b}$ \\ and Jaísa F. Soares ${ }^{*, a}$ \\ ${ }^{a}$ Departamento de Química, Universidade Federal do Paraná, Centro Politécnico, 81531-990 Curitiba - PR, Brazil \\ ${ }^{b}$ Department of Chemistry, CPES, University of Sussex, Brighton, BN1 9QJ, UK \\ ${ }^{c}$ Departamento de Química, Universidade Federal de Santa Maria, Campus Universitário, 97119-900 \\ Santa Maria - RS, Brazil \\ ${ }^{d}$ Departamento de Química, Universidade Federal de Minas Gerais, Pampulha, 31270-901 Belo Horizonte - MG, Brazil
}

\begin{abstract}
O novo cloroisopropóxido binuclear de titânio(IV), [ $\left.\left\{\mathrm{TiCl}\left(\mathrm{OPr}^{\mathrm{i}}\right)_{2}\left(\mathrm{HOPr}^{\mathrm{i}}\right)\right\}_{2}(\mu \text {-OPri })_{2}\right](\mathbf{1})$, e o primeiro oxo-cloroalcoolato de vanádio(IV) mononuclear, $\left[\mathrm{VCl}(\mathrm{O})\left(\mathrm{HOPr}^{\mathrm{i}}\right)_{4}\right] \mathrm{Cl}(\mathbf{2})$, foram preparados através da reação entre $\left[\mathrm{Ti}\left(\mathrm{OPr}^{\mathrm{i}}\right)_{4}\right], \mathrm{KOPr}^{\mathrm{i}}$ e $\mathrm{VCl}_{3}$ em proporção 2:1:1. Os produtos foram caracterizados por análise elementar, espectroscopia na região do infravermelho, RPE, RMN, espectroscopia eletrônica, medidas de susceptibilidade magnética e difratometria de raios-X (monocristal). A estrutura eletrônica de $\mathbf{1}$ foi analisada através de cálculos mecânico-quânticos em nível semi-empírico. Esses complexos são precursores em potencial de óxidos homo- e heterometálicos.
\end{abstract}

The novel binuclear titanium(IV) complex $\left[\left\{\mathrm{TiCl}\left(\mathrm{OPr}^{\mathrm{i}}\right)_{2}\left(\mathrm{HOPr}^{\mathrm{i}}\right)\right\}_{2}\left(\mu-\mathrm{OPr}^{\mathrm{i}}\right)_{2}\right], \mathbf{1}$, and the first mononuclear vanadyl(IV) chloroalcoholate $\left[\mathrm{VCl}(\mathrm{O})\left(\mathrm{HOPr}^{\mathrm{i}}\right)_{4}\right] \mathrm{Cl}, 2$, have been prepared from 2:1:1 mixtures of $\left[\mathrm{Ti}\left(\mathrm{OPr}_{4}\right)_{4}\right], \mathrm{KOPr}^{\mathrm{i}}$ and $\mathrm{VCl}_{3}$. Products were characterised by elemental analysis, FTIR, EPR, NMR and electronic spectroscopies, magnetic susceptibility measurements and single crystal $\mathrm{X}$-ray diffractometry. A third product was found to be polynuclear and to contain both titanium and vanadium. Semi-empirical quantum-mechanical calculations were carried out for the evaluation of the electronic structure of $\mathbf{1}$.

Keywords: titanium(IV), vanadium(IV), alkoxides, binuclear

\section{Introduction}

We have been interested in the preparation of heterometallic alkoxides of early transition metals (TM) as precursors for nitrogen fixation catalysts ${ }^{1}$ because some vanadium, iron and titanium complexes with $O$-donor ligands have demonstrated $\mathrm{N}_{2}$ chemistry. ${ }^{2,3}$ This work extends our previous reports on self-assembled early TM polynuclear systems. ${ }^{4}$

Although titanium alkoxides have been studied since the 40s, the remarkable variety of structural arrangements and synthetic approaches makes the search of general features a challenge to the inorganic chemist. Vanadium(III)

* e-mail: jaisa@quimica.ufpr.br and -(IV) alkoxides, on the other hand, are much less understood. The few reports on $\mathrm{V}^{\mathrm{III}}$ alkoxides and alcoholates leave open many questions on their real structure. ${ }^{5}$ Vanadium(IV) haloalkoxide alcoholates, $\mathrm{VCl}_{2}(\mathrm{OR})_{2} \cdot \mathrm{ROH}$, were prepared in 1950 by reaction of $\mathrm{VCl}_{4}$ with alcohols, in early attempts to obtain the elusive nonoxo vanadium(IV) alkoxides, $\left[\mathrm{V}(\mathrm{OR})_{4}\right] .^{6}$ These were later prepared by other methods. ${ }^{7}$ Vanadyl(IV) haloalkoxides were isolated from the reduction of $\left[\mathrm{VO}_{2} \mathrm{Cl}_{2}\right]^{-}$by alcohol, and the persistence of the binuclear $\left\{\mathrm{V}_{2} \mathrm{O}_{2}\right\}$ core in the products led to questions on earlier interpretations of reactivity patterns based on mononuclear oxovanadium sites. $^{8}$

This work describes the high-yield preparation of a novel titanium(IV) binuclear chloroisopropoxide complex, 
$\left[\left\{\mathrm{TiCl}\left(\mathrm{OPr}^{\mathrm{i}}\right)_{2}(\mathrm{Pr} \mathrm{OH})\right\}_{2}\left(\mu-\mathrm{OPr}^{\mathrm{i}}\right)_{2}\right](\mathbf{1})$, together with the first mononuclear vanadyl(IV) chloroalcoholate to be reported, $\left[\mathrm{VCl}(\mathrm{O})\left(\mathrm{HOPr}^{\mathrm{i}}\right)_{4}\right] \mathrm{Cl}(\mathbf{2})$. A third crystalline product (3) was obtained from the same reaction, and an unrefined crystal structure determination suggests a polynuclear ionic structure containing both titanium(IV) and vanadium(IV).

Complexes 1-3 were prepared in an attempt to make the vanadium analogue of the trinuclear $\left[\mathrm{FeCl}\left\{\mathrm{Ti}_{2}\left(\mathrm{OPr}^{\mathrm{i}}\right)_{9}\right\}\right]$, the first structurally characterised titanium and iron polynuclear isopropoxide, reported earlier by our group. ${ }^{1}$ The general synthetic route involves a salt-elimination reaction between $\mathrm{MCl}_{\mathrm{n}}(\mathrm{n}=2$ or $3 ; \mathrm{M}=$ transition metal) and the trinuclear $\left[\mathrm{M}^{\prime}\left\{\mathrm{Ti}_{2}\left(\mathrm{OPr}^{\mathrm{i}}\right)_{9}\right\}\right], \mathrm{M}^{\prime}=$ alkali metal, the

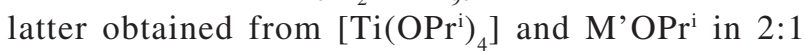
proportion. In this work, $\mathrm{VCl}_{3}$ was employed and its ease of hydrolysis and oxidation probably led to the unexpected products.

\section{Experimental}

\section{General}

All operations were carried out under $\mathrm{N}_{2}$ atmosphere with the use of standard Schlenk techniques, unless otherwise stated. Solvents (Carlo Erba) were dried by standard procedures ${ }^{9}$ and distilled twice under $\mathrm{N}_{2}$ prior to use.

Microanalyses were carried out by Medac Laboratories Ltd., Egham, Surrey, UK. Titanium and vanadium analyses were performed by ICP-OES at the Institute of Chemistry, University of São Paulo - SP (IQ-USP), Brazil, using Spectroflame Sequential equipment from Spectro Co., operating at $1.2 \mathrm{~kW}$. Samples were weighed under $\mathrm{N}_{2}$ and dissolved in $3 \mathrm{~mol} \mathrm{~L}^{-1} \mathrm{HCl}$ before analysis.

NMR solvents, supplied by Aldrich, were dried by the freeze-pump-thaw technique and kept under dinitrogen in Schlenk tubes equipped with grease-free taps. NMR spectra were obtained at $300 \mathrm{~K}$ in the appropriate deuterated solvents using Bruker Advance DRX-400 or Bruker AC80 equipment. Tetramethylsilane was used as reference. Variable-temperature NMR experiments were carried out in $\mathrm{CD}_{2} \mathrm{Cl}_{2}$ solution, in the temperature range $25 \rightarrow-55^{\circ} \mathrm{C}$ $(298 \rightarrow 218 \mathrm{~K})$ using a Bruker AC-200 spectrometer.

IR data (Nujol mulls) were recorded on Bomem Hartmann Braun equipment (MB series) in the range of $400-4000 \mathrm{~cm}^{-1}$. Samples were prepared under dinitrogen and spread on KBr plates. UV-Visible spectra were obtained at room temperature from Nujol mulls or from hexane solutions using an HP 8452A spectrophotometer.

EPR data (X-band, $9.5 \mathrm{GHz}$ ) were recorded on a Bruker ESP-300E instrument from solid samples or toluene solutions at room temperature and at $77 \mathrm{~K}$. Magnetic susceptibility measurements by a modified Gouy method were carried out in solution at room temperature using a MKII magnetic susceptibility balance from JohnsonMatthey. Corrections for the diamagnetism of the ligands were applied. ${ }^{10}$

Commercial vanadium(III) chloride (Aldrich) and titanium(IV) chloride (Merck) were used without further purification. Anhydrous propan-2-ol (Aldrich) was distilled from sodium and calcium hydride. Research grade liquefied ammonia (99.99\%) was supplied by Praxair. Sodium hydride (60\% dispersion in mineral oil), supplied by Aldrich, was purified by a literature method. $\mathrm{NaOPr}^{\mathrm{i}}$ was prepared by the reaction of a large excess of propan-2ol with pure NaH. ${ }^{11}$ The yield was quantitative.

$\left[\mathrm{Ti}\left(\mathrm{OPr}^{\mathrm{i}}\right)_{4}\right]$ was prepared according to the method of Bradley and co-workers, ${ }^{12}$ by treatment of a toluene solution of titanium tetrachloride with propan-2-ol, followed by bubbling an excess of dry ammonia. After the removal of ammonium chloride and solvent, the titanium tetraisopropoxide was distilled under reduced pressure. Typical yields were $c a .50 \%$. Titanium content, found (calculated): $16.8(16.8) \% . \delta_{\mathrm{H}}\left(400 \mathrm{MHz}, \mathrm{C}_{6} \mathrm{D}_{6}, 20{ }^{\circ} \mathrm{C}\right)$ $1.26(6 \mathrm{H}, \mathrm{d})$ and $4.54\left(1 \mathrm{H}\right.$, septet). $\delta_{\mathrm{C}}\left(400 \mathrm{MHz}, \mathrm{C}_{6} \mathrm{D}_{6}\right.$, $\left.20^{\circ} \mathrm{C}\right) 26.75,-\mathrm{CH}_{3}$, and $76.36,-\mathrm{CH}-$. IR $v_{\max } / \mathrm{cm}^{-1}: 1124 \mathrm{vs}$, $1006 v s, v(\mathrm{C}-\mathrm{O}) ; 621 \mathrm{~s}, v(\mathrm{Ti}-\mathrm{O})$.

\section{Synthesis}

$\left[\mathrm{Ti}\left(\mathrm{OPr}^{\mathrm{i}}\right)_{4}\right]\left(8.8 \mathrm{~cm}^{3}, 8.5 \mathrm{~g}, 29.9 \mathrm{mmol}\right)$ was added to a suspension of $1.3 \mathrm{~g}(15.0 \mathrm{mmol})$ of $\mathrm{NaOPr}$ in $40 \mathrm{~cm}^{3}$ of toluene. The reaction mixture was heated at $70{ }^{\circ} \mathrm{C}$ for $5 \mathrm{~h}$ to give a colourless solution. A suspension of $\mathrm{VCl}_{3}(2.3 \mathrm{~g}$, $14.9 \mathrm{mmol})$ in toluene/propan-2-ol (10:1) was then added to the mixture, which was kept under reflux at $70{ }^{\circ} \mathrm{C}$ for two more days. The resulting olive-green suspension was filtered to give a greenish-brown solid (1.3 g), insoluble in toluene, propan-2-ol, hexane, dichloromethane, tetrahydrofuran and acetonitrile. This was washed with $20 \mathrm{~cm}^{3}$ of toluene and dried under vacuum. To the brown filtrate, concentrated under vacuum to $c a .20 \mathrm{~cm}^{3}$, propan2-ol $\left(20 \mathrm{~cm}^{3}\right)$ was added, giving a clear green solution that was cooled down to $-20{ }^{\circ} \mathrm{C}$. Colourless crystals $(5.3 \mathrm{~g}$; $55 \%$ yield of $\mathbf{1}$ ) were isolated by filtration, dried under $\mathrm{N}_{2}$ and recrystallised from toluene/propan-2-ol 1:1 to produce single crystals suitable for X-ray structure determination (64\% recovery after recrystallisation). Product $\mathbf{1}$ is soluble in toluene, hexane, dichloromethane, acetonitrile (room temperature) and in hot propan-2-ol $\left(c a .50{ }^{\circ} \mathrm{C}\right)$. It is insoluble in methanol and diethyl ether. From the mother liquor, which was further concentrated under vacuum and 
received a second addition of propan-2-ol, a bluish-green polycrystalline material, $2(0.55 \mathrm{~g})$ was filtered off and dried under $\mathrm{N}_{2}$. This material was recrystallised at $-20{ }^{\circ} \mathrm{C}$ in a mixture of toluene/propan-2-ol/hexane in the proportion 4:1:5. Product 2 is soluble in toluene, tetrahydrofuran and dichloromethane and insoluble in propan-2-ol and hexane. The addition of $15 \mathrm{~cm}^{3}$ of hexane to the mother liquor led to the isolation of a small amount of green crystals, product $\mathbf{3}$, which were soluble in toluene and insoluble in hexane and propan-2-ol. Found for 1: C, 44.1; $\mathrm{H}, 9.1$; Ti, 14.2\%. $\mathrm{C}_{24} \mathrm{H}_{58} \mathrm{Cl}_{2} \mathrm{O}_{8} \mathrm{Ti}_{2}$ Calcd. for: C, 44.9; $\mathrm{H}, 9.1$; Ti, $14.9 \%$. IR $v_{\max } / \mathrm{cm}^{-1}: 3334 \mathrm{~m}$ and $3199 \mathrm{~m}$ (br), $v(\mathrm{O}-\mathrm{H}) ; 1325 \mathrm{w}$ and $1261 \mathrm{w}, v(\mathrm{C}-\mathrm{C}) ; 1164 \mathrm{~m}, \delta\left(\mathrm{CH}_{3}\right) ; 1012 \mathrm{vs}$, $v(\mathrm{C}-\mathrm{O})$, terminal $-\mathrm{OPr}$; $933 \mathrm{~m}, v(\mathrm{C}-\mathrm{O})$, bridging $-\operatorname{OPr}^{\mathrm{i}} ; 860 \mathrm{~m}$, $817 \mathrm{~m}$ and $794 \mathrm{w}, v_{\mathrm{s}}(\mathrm{CCC}) ; 617 \mathrm{~s}(\mathrm{br}), v(\mathrm{C}-\mathrm{O})$ and $v(\mathrm{Ti}-\mathrm{O}) .{ }^{13}$

Found for 2: C, 35.6; $\mathrm{H}, 8.5 \% . \mathrm{C}_{12} \mathrm{H}_{32} \mathrm{Cl}_{2} \mathrm{O}_{5} \mathrm{~V}$ Calcd. for: $\mathrm{C}, 38.1 ; \mathrm{H}, 8.5 \%$. The very high moisture sensitivity of 2, which makes it difficult to handle, has probably determined the low carbon figures. IR $v_{\max } / \mathrm{cm}^{-1}: 3340 \mathrm{~m}$ (br) and 3150m (br), $v(\mathrm{O}-\mathrm{H}) ; 1297 \mathrm{w}$ and $1259 \mathrm{w} v(\mathrm{C}-\mathrm{C})$; $1163 \mathrm{w}, \delta\left(\mathrm{CH}_{3}\right) ; 1135 \mathrm{w}, 1093 \mathrm{~s}$ and $1018 \mathrm{w}, v(\mathrm{C}-\mathrm{O}) ; 983 \mathrm{~m}$, $v(\mathrm{~V}=\mathrm{O}) ; 925 \mathrm{~s}, \delta\left(\mathrm{CH}_{3}\right) ; 877 \mathrm{w}$ and $813 \mathrm{~s}, \nu_{\mathrm{s}}(\mathrm{CCC}) ; 638 \mathrm{w}(\mathrm{br})$ and $547 \mathrm{w}(\mathrm{br}) \nu(\mathrm{V}-\mathrm{O}) . \mu_{\mathrm{eff}}=1.82 \mu_{\mathrm{B}}$.

\section{Single-crystal $X$-ray diffraction analyses}

Data were collected on a Nonius Kappa CCD area detector diffractometer at Department of Chemistry, University of Sussex, Brighton, UK. A suitable colourless crystal of $1\left(0.3 \times 0.2 \times 0.2 \mathrm{~mm}^{3}\right)$ and a bluish-green crystal of $2\left(0.20 \times 0.05 \times 0.05 \mathrm{~mm}^{3}\right)$ were mounted on glass fibres and cooled to $173(2) \mathrm{K}$. Cell dimensions were based on all 2714 and 1173 observed reflections (I $>2 \sigma_{\mathrm{I}}$ ) for $\mathbf{1}$ and $\mathbf{2}$, respectively. Structures were solved by direct methods using the program package WinGX ${ }^{14}$ and refined by full-matrix least-squares on $\mathrm{F}^{2}$ with SHELXL-97. ${ }^{15}$ Drawings were made with ORTEP-3 for Windows. ${ }^{14}$ Absorption corrections were carried out with MULTISCAN. All non-hydrogen atoms were refined anisotropically. The hydrogen atom on $\mathrm{O}$ (4) (complex 1) was freely refined. In product 2 , the molecule lies on a crystallographic 2-fold rotation axis with the $\mathrm{Cl}(1)$ and $\mathrm{O}(1)$ atoms disordered and unresolved. Details on data collections and structure refinements are presented in Table 1.

\section{Quantum mechanical methods and computational details}

Calculations for complex 1 were carried out with the INDO code, ${ }^{16}$ running on a IBM-PC compatible microcomputer at the Department of Chemistry - UFPR. For the stability calculation, overlap integrals were calculated $a b$ initio over a minimum basis set of Slater-type orbitals
Table 1. Crystal and structure refinement data for $\left[\left\{\mathrm{TiCl}\left(\mathrm{OPr}^{\mathrm{i}}\right)_{2}\left(\mathrm{Pr}^{\mathrm{i} O H}\right)\right\}_{2}\left(\mu-\mathrm{OPr}^{\mathrm{i}}\right)_{2}\right](\mathbf{1})$, and $\left[\mathrm{VCl}(\mathrm{O})\left(\mathrm{HOPr}^{\mathrm{i}}\right)_{4}\right] \mathrm{Cl}(\mathbf{2})$

\begin{tabular}{|c|c|c|}
\hline & 1 & 2 \\
\hline Empirical formula & $\mathrm{C}_{24} \mathrm{H}_{58} \mathrm{Cl}_{2} \mathrm{O}_{8} \mathrm{Ti}_{2}$ & $\mathrm{C}_{12} \mathrm{H}_{32} \mathrm{Cl}_{2} \mathrm{O}_{5} \mathrm{~V}$ \\
\hline Formula weight, $\mathrm{g} \cdot \mathrm{mol}^{-1}$ & 641.40 & 378.22 \\
\hline Temperature, K & 173(2) & 173(2) \\
\hline Crystal system & Monoclinic & Monoclinic \\
\hline Space group & $\mathrm{P} 2_{1} / \mathrm{n}($ no. 14$)$ & C2/c (no. 15) \\
\hline $\mathrm{a}, \AA$ & $10.8611(4)$ & $15.7110(7)$ \\
\hline $\mathrm{b}, \AA$ & $10.5932(5)$ & $11.3653(5)$ \\
\hline $\mathrm{c}, \AA$ & $15.3648(5)$ & $11.6381(5)$ \\
\hline$\beta,{ }^{\circ}$ & $102.826(2)$ & $90.466(2)$ \\
\hline $\mathrm{V}, \AA^{3}$ & $1723.67(12)$ & $2078.0(2)$ \\
\hline $\mathrm{F}(000)$ & 688 & 804 \\
\hline $\mathrm{Z}$ & 2 & 4 \\
\hline$\rho_{\text {calcd }}, \mathrm{mg} \mathrm{m}^{-3}$ & 1.24 & 1.21 \\
\hline$\lambda\left(\mathrm{Mo}, \mathrm{K}_{\alpha}\right), \AA$ & 0.71073 & 0.71073 \\
\hline$\mu, \mathrm{mm}^{-1}$ & 0.66 & 0.75 \\
\hline$\theta$ range, ${ }^{\circ}$ & 4.61 to 25.04 & 3.99 to 22.98 \\
\hline Reflections collected & 10969 & 7789 \\
\hline Independent reflections & $2982\left(\mathrm{R}_{\mathrm{int}}=0.030\right)$ & $1448\left(\mathrm{R}_{\mathrm{int}}=0.056\right)$ \\
\hline Reflections with $I>2 \sigma_{\mathrm{I}}$ & 2714 & 1173 \\
\hline Parameters refined & 167 & 101 \\
\hline $\mathrm{R}_{1}, \mathrm{wR}_{2}\left(\mathrm{I}>2 \sigma_{\mathrm{I}}\right)^{\mathrm{a}}$ & $0.041,0.101$ & $0.056,0.111$ \\
\hline $\mathrm{R}_{1}, \mathrm{wR}_{2}$ (all data) & $0.045,0.105$ & $0.075,0.121$ \\
\hline
\end{tabular}

${ }^{a}$ as defined by the SHELXL-97 program. ${ }^{15}$

(STOs). ${ }^{17}$ For the evaluation of electronic spectra, the INDO/ $\mathrm{S}$ parametrization developed by Zerner and co-workers and available in the Argus Lab-2.0 program was employed, ${ }^{18}$ with the two-electron integrals of the form $\gamma_{\mu \nu}$ $=(\mu \mu \mid v v)$ calculated by a modified Mataga-Nishimoto method. ${ }^{19}$ The CI/ROHF theoretical calculations employed atomic coordinates taken from the experimental X-ray geometry. The CI space included the ground state plus 121 single excitations (HOMO-4 $\rightarrow$ HOMO and LUMO $\rightarrow$ LUMO+7)

\section{Results and Discussion}

In the attempt to prepare the heterometallic $\left[\mathrm{VCl}_{2}\left\{\mathrm{Ti}_{2}\left(\mathrm{OPr}^{\mathrm{i}}\right)_{9}\right\}\right]$ by the route that gave $\left[\mathrm{FeCl}\left\{\mathrm{Ti}_{2}\left(\mathrm{OPr}^{\mathrm{i}}\right)_{9}\right\}\right],{ }^{1}$ the reaction between $\left[\mathrm{Ti}\left(\mathrm{OPr}^{\mathrm{i}}\right)_{4}\right]$ and $\mathrm{NaOPr}^{\mathrm{i}}(2: 1)$ was carried out in toluene/propan-2-ol solution, followed by the addition of one equivalent of $\mathrm{VCl}_{3}$. After work-up, three crystalline products were isolated (Scheme 1). Elemental analyses for complexes 1 and $\mathbf{2}$ indicated that the two transition metals were incorporated into different products, as the colourless $\mathbf{1}$, obtained in high yield, contained only titanium, while the bluish-green 2 was a vanadium complex. The full characterisation of the green $\mathbf{3}$ was hampered by the small amount of product isolated from the reaction mixture. Because of poor crystal quality, the results of the X-ray 
diffraction analysis of $\mathbf{3}$ only suggest an ionic structure composed of a $\left[\mathrm{Ti}_{3}\left(\mathrm{OPr}^{\mathrm{i}}\right)_{11}\right]^{+}$cation and a tetranuclear vanadyl(IV) oxoalkoxo anion. Attempts to get better crystals are currently under way.

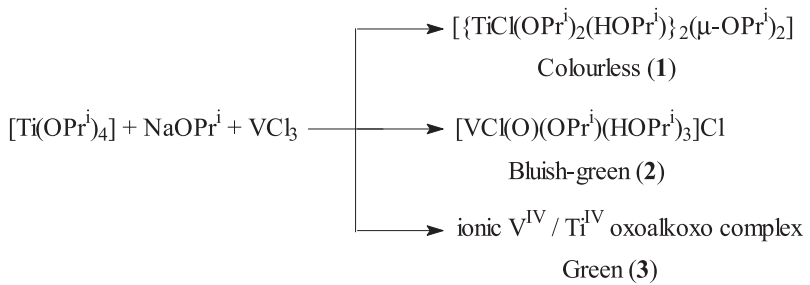

Scheme 1. Products of the reaction involving $\left.\left[\mathrm{Ti}_{(\mathrm{OPr}}\right)_{4}\right], \mathrm{KOPr}^{\mathrm{i}}$ and $\mathrm{VCl}_{3}$.

\section{Product 1}

The complex is EPR-silent at room temperature and at $77 \mathrm{~K}$, and diamagnetic when submitted to roomtemperature magnetic susceptibility measurements. In the FTIR spectrum, a strong set of bands centred at $617 \mathrm{~cm}^{-1}$ can be assigned to $v$ (Ti-O). ${ }^{20}$ The band at $933 \mathrm{~cm}^{-1}$ is given by $\mathrm{C}-\mathrm{O}$ stretching in bridging isopropoxides and suggests a polynuclear structure. ${ }^{13}$ The spectra also indicate that $\mathbf{1}$ contains propan-2-ol and isopropoxide as terminal ligands (see Experimental).

An ORTEP representation of the molecular structure of 1 is shown in Figure 1. Crystallographic data and selected geometric parameters are listed in Tables 1 and 2. The molecule lies on a crystallographic inversion centre. The structure consists of two six-coordinate titanium centres, each one with one chloride, two isopropoxides and one alcohol molecule as terminal ligands. Two bridging isopropoxides complete the edge-sharing distorted octahedral coordination of the two titanium(IV) centres. A central feature of the structure is the planar $\mathrm{Ti}\left(\mu-\mathrm{OPr}^{\mathrm{i}}\right)_{2} \mathrm{Ti}$ core, with unsymmetrical Ti-O(1) and Ti-O(1)' distances of 2.1043(15) and 1.9521(15) $\AA$, respectively. These distances are comparable to the analogous dimensions in $\left[\left\{\mathrm{TiCl}_{2}\left(\mathrm{OCH}_{2} \mathrm{CH}_{2} \mathrm{Cl}\right)_{2} \cdot \mathrm{HOCH}_{2} \mathrm{CH}_{2} \mathrm{Cl}\right\}_{2}\right] .{ }^{21}$ The short Ti-O(3) bond $(1.7690(16) \AA)$ is trans to the long Ti-O(1) dimension in the bridge, while the Ti-Cl bond is trans to the shorter Ti-O(1)' distance. This suggests a stronger trans influence for terminal alkoxide than for terminal chloride in $\mathbf{1}$.

The C(7)-O(3)-Ti(1) angle is $150.14(17)^{\circ}$, much larger than the expected tetrahedral magnitude for an $\mathrm{sp}^{3}$ hybridized $\mathrm{O}(3)$. This is accounted for by strong $\pi$-bonding between the alkoxide and the metal..$^{22}$ The $\mathrm{C}(4)-\mathrm{O}(2)-\mathrm{Ti}$ and $\mathrm{C}(10)-\mathrm{O}(4)-\mathrm{Ti}$ angles for the axial isopropoxide and propan-2-ol ligands are smaller at $131.99(14)^{\circ}$ and $135.90(16)^{\circ}$ respectively, indicating a lower degree of

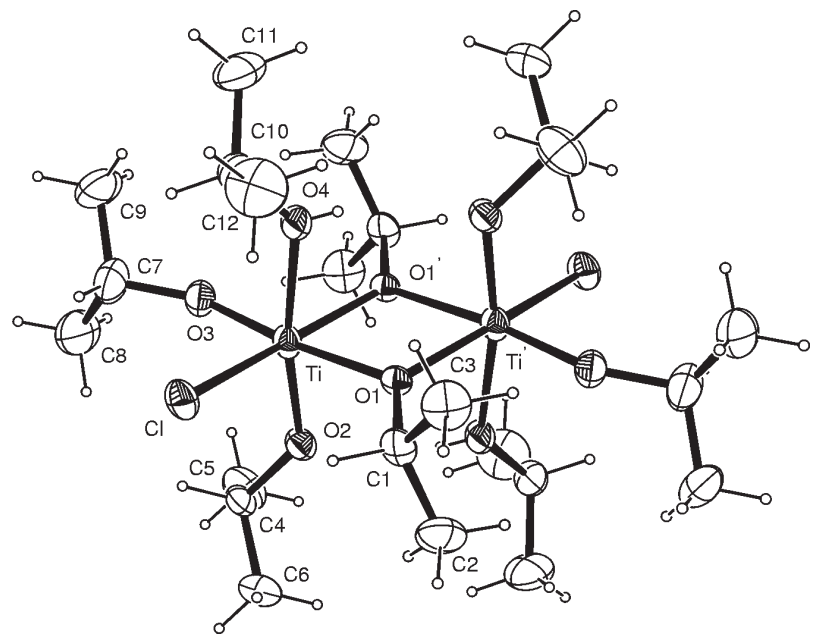

Figure 1. ORTEP representation of the molecular structure of $\left[\left\{\mathrm{TiCl}\left(\mathrm{OPr}^{\mathrm{i}}\right)_{2}\left(\mathrm{HOPr}^{\mathrm{i}}\right)\right\}_{2}(\mu \text {-OPri })_{2}\right](\mathbf{1})$ showing thermal ellipsoids drawn at $50 \%$ probability.

Table 2. Selected bond lengths ( $\AA$ ) and angles (deg) for $\left[\left\{\mathrm{TiCl}\left(\mathrm{OPr}_{2}^{\mathrm{i}}\right)_{2}\left(\mathrm{Pr}^{\mathrm{i}} \mathrm{OH}\right)\right\}_{2}\left(\mu-\mathrm{OPr}^{\mathrm{i}}\right)_{2}\right](\mathbf{1})$

\begin{tabular}{|c|c|c|c|}
\hline \multicolumn{4}{|l|}{ Bond lengths } \\
\hline $\mathrm{Ti}-\mathrm{O}(1)$ & $2.1043(15)$ & $\mathrm{Ti}-\mathrm{O}(3)$ & $1.7690(16)$ \\
\hline $\mathrm{Ti}-\mathrm{O}(1)^{\prime}$ & $1.9521(15)$ & $\mathrm{Ti}-\mathrm{O}(4)$ & $2.1824(18)$ \\
\hline \multirow[t]{2}{*}{$\mathrm{Ti}-\mathrm{O}(2)$} & $1.8533(16)$ & $\mathrm{Ti}-\mathrm{Cl}$ & $2.3846(6)$ \\
\hline & $\mathrm{Ti} \cdots \mathrm{Ti}$ & $3.205(1)$ & \\
\hline \multicolumn{4}{|l|}{ Angles } \\
\hline $\mathrm{O}(2)-\mathrm{Ti}-\mathrm{O}(3)$ & $100.06(8)$ & $\mathrm{O}(1)^{\prime}-\mathrm{Ti}-\mathrm{Cl}$ & $163.40(5)$ \\
\hline $\mathrm{O}(2)-\mathrm{Ti}-\mathrm{O}(4)$ & $167.99(8)$ & $\mathrm{O}(2)-\mathrm{Ti}-\mathrm{Cl}$ & $95.21(5)$ \\
\hline $\mathrm{O}(2)-\mathrm{Ti}-\mathrm{O}(1)$ & $86.92(7)$ & $\mathrm{O}(3)-\mathrm{Ti}-\mathrm{Cl}$ & $88.78(5)$ \\
\hline $\mathrm{O}(2)-\mathrm{Ti}-\mathrm{O}(1)$ & $94.49(7)$ & $\mathrm{O}(4)-\mathrm{Ti}-\mathrm{Cl}$ & $86.59(5)$ \\
\hline $\mathrm{O}(3)-\mathrm{Ti}-\mathrm{O}(4)$ & $91.83(8)$ & $\mathrm{Ti}-\mathrm{O}(1)-\mathrm{C}(1)$ & $127.01(13)$ \\
\hline $\mathrm{O}(3)-\mathrm{Ti}-\mathrm{O}(1)$ & $172.97(7)$ & $\mathrm{Ti}^{\prime}-\mathrm{O}(1)-\mathrm{C}(1)$ & $128.36(13)$ \\
\hline $\mathrm{O}(3)-\mathrm{Ti}-\mathrm{O}(1)$ & $102.74(7)$ & $\mathrm{Ti}-\mathrm{O}(2)-\mathrm{C}(4)$ & $131.99(14)$ \\
\hline $\mathrm{O}(4)-\mathrm{Ti}-\mathrm{O}(1)$ & $81.17(7)$ & $\mathrm{Ti}-\mathrm{O}(3)-\mathrm{C}(7)$ & $150.14(17)$ \\
\hline $\mathrm{O}(4)-\mathrm{Ti}-\mathrm{O}(1)$ & $81.19(6)$ & $\mathrm{Ti}-\mathrm{O}(4)-\mathrm{C}(10)$ & $135.90(16)$ \\
\hline $\mathrm{O}(1)-\mathrm{Ti}-\mathrm{O}(1)$ & $75.67(6)$ & $\mathrm{Ti}-\mathrm{O}-\mathrm{Ti}^{\prime}$ & $104.33(6)$ \\
\hline $\mathrm{O}(1)-\mathrm{Ti}-\mathrm{Cl}$ & $91.43(4)$ & & \\
\hline
\end{tabular}

$\pi$-bonding. The significantly different $\mathrm{Ti}-\mathrm{O}(2)$ and $\mathrm{Ti}-\mathrm{O}(4)$

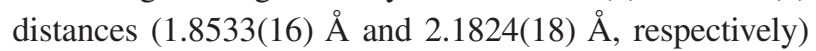
differentiate the coordinated alkoxide from the alcohol ligand. The $\mathrm{O}(1)-\mathrm{Ti}-\mathrm{O}(1)^{\prime}$ angle $\left(75.67^{\circ}\right)$ is constrained by the $\operatorname{Ti}\left(\mu-\mathrm{OPr}^{\mathrm{i}}\right)_{2} \mathrm{Ti}$ core, whereas the other equatorial angles are determined by ring restrictions, $\mathrm{Pr} \mathrm{O} \cdot \cdots \mathrm{Cl}$ repulsions and by the isopropyl steric effect.

The oxygen atom of the alcohol ligand, $\mathrm{O}(4)$, is bent towards $\mathrm{O}(2)^{\prime}$, which is bound to the other titanium centre (Figure 2). This is shown by the difference between the $\mathrm{O}(2)$-Ti-Ti' and the $\mathrm{O}(4)$-Ti-Ti' angles $\left(90.68^{\circ}\right.$ versus $\left.78.8^{\circ}\right)$ and by the distance $\mathrm{O}(4) \cdots \mathrm{O}(2)^{\prime}(2.8269 \AA)$, which is $c a$.

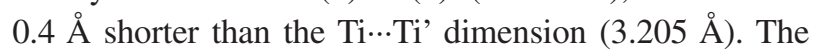
FTIR spectrum of $\mathbf{1}$ is consistent with this, as it shows a 
medium-intensity, broad hydroxyl absorption at $3200 \mathrm{~cm}^{-1}$, assigned to the presence of a hydrogen bond involving $\mathrm{O}(4)-\mathrm{H} \cdots \mathrm{O}(2)^{\prime} \mathrm{Pr}^{\mathrm{i}}$. The existence of such intramolecular interaction between $\mathrm{MRO}-\mathrm{H} \cdots \mathrm{A}(\mathrm{A}=\mathrm{Cl}, \mathrm{OR})$ groups is a structural characteristic of dimeric alkoxides similar to $1 .^{23}$

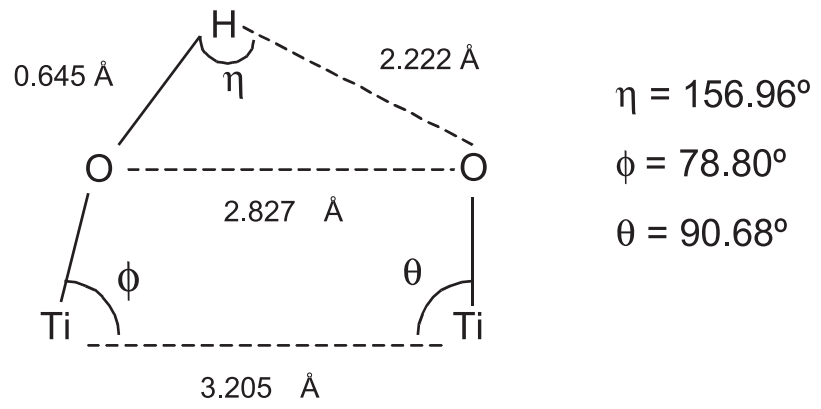

Figure 2. Intramolecular hydrogen bonding in $\mathbf{1}$.

The method usually employed for the preparation of binuclear titanium alkoxides is the alcoholysis of $\mathrm{TiCl}_{4}$.
However, by this procedure no more than two chlorides can be replaced on each Ti centre, even with a large excess of the alcohol.$^{24}$ Product $\mathbf{1}$, obtained by a different route, is the first binuclear titanium haloalkoxide which contains only one chloride per metal centre. This chloride was actually donated by the $\mathrm{VCl}_{3}$.

Room temperature ${ }^{1} \mathrm{H}-\mathrm{NMR}$ spectra of 1 in $\mathrm{CD}_{2} \mathrm{Cl}_{2}$ gave a broad signal at $\delta 4.50 \mathrm{ppm}$ for the methine $(-\mathrm{CH})$ hydrogens and two signals at $\delta 1.27$ and $\delta 1.30 \mathrm{ppm}$ assigned to the methyl hydrogens of the isopropyl group. The broad resonances are due to the presence of isopropoxide and propan-2-ol in very similar chemical environments, added to the fluxional character of these groups in solution at room temperature. ${ }^{24}$

Variable temperature ${ }^{1} \mathrm{H}-\mathrm{NMR}$ spectra of $\mathbf{1}$ (Figure 3) show significant changes on lowering the temperature. At $-20{ }^{\circ} \mathrm{C}$, at least two sets of signals were detected in the methine hydrogen region. The signals at $\delta 5.1$ and $\delta 4.2$ ppm are due to the isopropoxide and propan-2-ol groups respectively. At -30 and $-40{ }^{\circ} \mathrm{C}$ three signals were observed
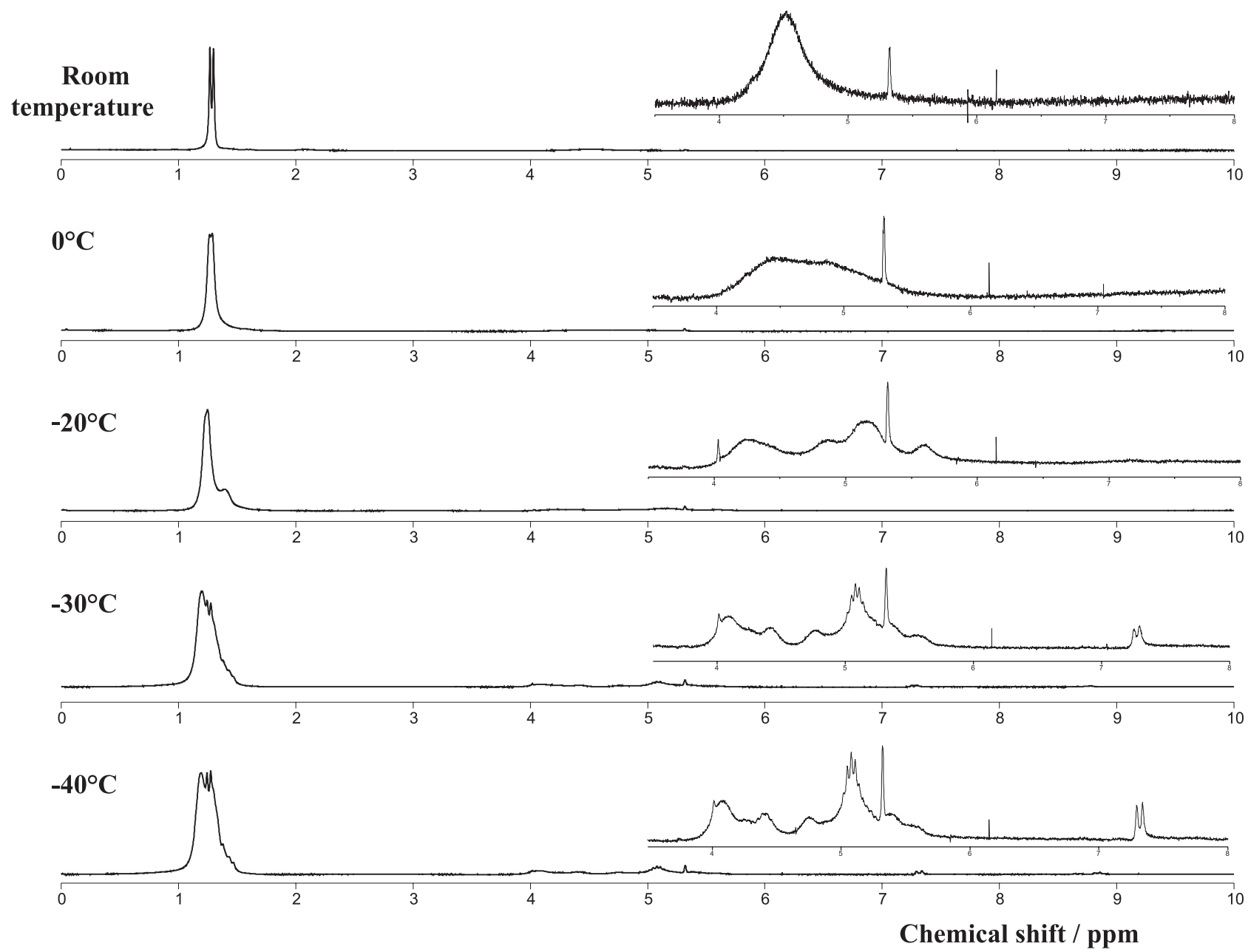

Figure 3. Variable temperature ${ }^{1} \mathrm{H}-\mathrm{NMR}$ spectra for $\mathbf{1}$ in $\mathrm{CD}_{2} \mathrm{Cl}_{2}$. 
for the methyl hydrogens. The resonance at $\delta 1.21 \mathrm{ppm}$ was assigned to propan-2-ol and those at $\delta 1.24$ and $\delta 1.28$ $\mathrm{ppm}$ to the terminal and bridging isopropoxides, respectively. A broad alcohol $(\mathrm{O}-\mathrm{H})$ resonance was seen as a doublet at $\delta 7.25 \mathrm{ppm}$. Such a large high frequency shift is consistent with hydrogen bonding. ${ }^{24}$ The three different environments for the $-\mathrm{OPr}^{\mathrm{i}}$ groups in $\mathbf{1}$ suggest that the dimeric structure determined by X-ray diffractometry is maintained in solution. Accordingly, the FTIR spectra for $\mathbf{1}$ in hexane solution and in the solid state are similar.

Semi-empirical quantum mechanical calculations were based on the molecular geometry determined by X-ray diffractometry. Relative energies were calculated for spin states between 1 and 3 . The ground state was shown to be a singlet, $624 \mathrm{~kJ} \mathrm{~mol}^{-1}$ below the nearest triplet. This is compatible with the presence of the two titanium(IV) centres in the molecule. Typical LMCT charge-transfer absorptions were found at 187, 182 and $171 \mathrm{~nm}$ and were assigned to $\mathrm{p}_{\pi}(\mathrm{Cl}) \rightarrow \mathrm{d}_{\pi}(\mathrm{Ti})$ and $\mathrm{p}_{\pi}(\mathrm{O}$, isopropoxide $) \rightarrow$ $\mathrm{d}_{\pi}(\mathrm{Ti})$ transitions. The chloride shows the highest partial negative charge in the molecule.

\section{Product 2}

The FTIR spectrum of 2 contains absorptions at $3340 \mathrm{~cm}^{-1}$, assigned to $v(\mathrm{O}-\mathrm{H})$, and at 1135,1093 and $1018 \mathrm{~cm}^{-1}$, due to the $\mathrm{C}-\mathrm{O}$ stretching of the terminal $\mathrm{HOPr}^{\mathrm{i}}$ ligands. The bands at 638 and $547 \mathrm{~cm}^{-1}$ were assigned to $v(\mathrm{~V}-\mathrm{O})$. The absorption at $983 \mathrm{~cm}^{-1}$ is strong evidence for a vanadyl $(\mathrm{V}=\mathrm{O})$ group in $\mathbf{2} .^{25}$

According to the X-ray diffraction analysis, $\mathbf{2}$ is composed of a mononuclear six-coordinate vanadium cation and an outer-sphere $\mathrm{Cl}^{-}$that is hydrogen-bonded to $\mathrm{HO}(2) \mathrm{R}$ and $\mathrm{HO}(3)$ 'R. Four propan-2-ol ligands, one chloride and one terminal oxo group determine the distorted octahedral geometry about the metal. A molecular view is shown in Figure 4 and selected angles and bond lengths are listed in Table 3.

The molecule lies on a crystallographic 2-fold rotation axis with $\mathrm{Cl}(1)$ and $\mathrm{O}(1)$ disordered. This makes the $\mathrm{V}-\mathrm{Cl}$ bond appear shorter and the $\mathrm{V}=\mathrm{O}$ longer. By checking similar dimensions in other complexes, one arrives to the conclusion that the V-O/V-Cl bond length in 2 (2.073(2) $\AA)$ is very close to the average value between well-resolved $\mathrm{V}=\mathrm{O}$ and $\mathrm{V}-\mathrm{Cl}$ bond dimensions in octahedral vanadyl(IV) complexes, as seen for example in $\left[\mathrm{VOCl}_{2}\left(\mathrm{OH}_{2}\right)(\mathrm{thf})_{2}\right] \cdot{ }^{26} \mathrm{In}$ this case, $\mathrm{V}=\mathrm{O}$ and $\mathrm{V}-\mathrm{Cl}$ distances are 1.584(4) $\AA$ and 2.400(11) A, respectively.

Room temperature magnetic susceptibility measurements have been carried out for $\mathbf{2}$ in toluene/ propan-2-ol solution. This gave an effective magnetic

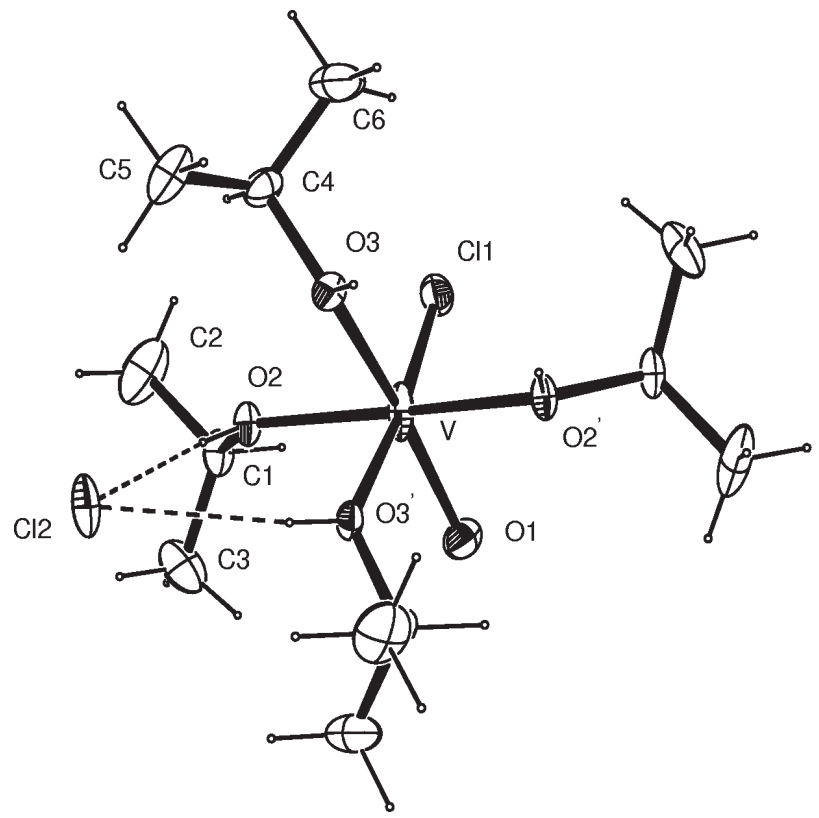

Figure 4. ORTEP representation of $\left[\mathrm{VCl}(\mathrm{O})\left(\mathrm{HOPr}^{\mathrm{i}}\right)_{4}\right] \mathrm{Cl}(\mathbf{2})$ showing thermal ellipsoids drawn at $20 \%$ probability.

Table 3. Selected bond lengths ( $\AA$ ) and angles (deg) for $\left[\mathrm{VCl}(\mathrm{O})\left(\mathrm{HOPr}^{\mathrm{i}}\right)_{4}\right] \mathrm{Cl}(\mathbf{2})$

\begin{tabular}{llll}
\hline $\begin{array}{l}\text { Bond lengths } \\
\mathrm{V}-\mathrm{O}(2)\end{array}$ & $2.036(3)$ & $\mathrm{O}(2)-\mathrm{C}(1)$ & $1.462(5)$ \\
$\mathrm{V}-\mathrm{Cl}(1) / \mathrm{O}(1)$ & $2.073(2)$ & $\mathrm{O}(3)-\mathrm{C}(4)$ & $1.455(5)$ \\
$\mathrm{V}-\mathrm{O}(3)$ & $2.132(3)$ & & \\
Angles & & & \\
$\mathrm{O}(2)-\mathrm{V}-\mathrm{O}(2)^{\prime}$ & $166.45(17)$ & $\mathrm{Cl}(1)-\mathrm{V}-\mathrm{O}(3)$ & $95.26(10)$ \\
$\mathrm{O}(2)-\mathrm{V}-\mathrm{Cl}(1)$ & $92.14(10)$ & $\mathrm{O}(1)-\mathrm{V}-\mathrm{O}(3)$ & $171.57(11)$ \\
$\mathrm{O}(2)^{\prime}-\mathrm{V}-\mathrm{Cl}(1)$ & $97.17(10)$ & $\mathrm{Cl}(1)-\mathrm{V}-\mathrm{O}(3)^{\prime}$ & $171.57(11)$ \\
$\mathrm{Cl}(1)-\mathrm{V}-\mathrm{O}(1)$ & $93.14(12)$ & $\mathrm{O}(3)^{\prime}-\mathrm{V}-\mathrm{O}(3)$ & $76.33(16)$ \\
$\mathrm{O}(2)-\mathrm{V}-\mathrm{O}(3)$ & $83.10(12)$ & $\mathrm{V}-\mathrm{O}(2)-\mathrm{C}(1)$ & $126.5(3)$ \\
$\mathrm{O}(2)^{\prime}-\mathrm{V}-\mathrm{O}(3)$ & $86.25(12)$ & $\mathrm{V}-\mathrm{O}(3)-\mathrm{C}(4)$ & $131.9(3)$ \\
\hline
\end{tabular}

moment $\left(\mu_{\text {eff }}=1.82 \mu_{\mathrm{B}}\right)$ slightly higher than the expected spin-only value for a $\mathrm{d}^{1}$ complex, which is accounted for by a small orbital contribution to the susceptibility. This agrees with the formation of a mononuclear complex as observed by X-ray diffractometry.

EPR spectra registered for $\mathbf{2}$ in toluene solution at room temperature exhibit the expected eight hyperfine lines arising from the interaction of the unpaired $3 \mathrm{~d}^{1}$ electron with the vanadium nucleus $(I=7 / 2)$. The correlation between the isotropic EPR parameters $\left(\mathrm{g}_{\text {iso }}=1.966 ; \mathrm{A}_{\text {iso }}=\right.$ $109.8 \mathrm{G}$ ) agrees well with other reports for vanadyl complexes with $O$-donor ligands. ${ }^{27,28}$ The anisotropic eightline spectrum at $77 \mathrm{~K}$ is resolved in parallel and perpendicular components $\left(\mathrm{g}_{\|}=1.936 ; \mathrm{g}_{\perp}=1.977 ; \mathrm{A}_{\|}=\right.$ 196.5 G; $\left.\mathrm{A}_{\perp}=72.4 \mathrm{G}\right)$, but the features associated with the 
$x$ and $y$ resonance fields are not split. This is probably because the anisotropy in the $\mathrm{g}_{\mathrm{xx}}, \mathrm{g}_{\mathrm{yy}}$ and $\mathrm{A}_{\mathrm{xx}}, \mathrm{A}_{\mathrm{yy}}$ tensor elements (predicted on the basis of the low point symmetry revealed by crystallography) is too small compared with the linewidths of the resonances. ${ }^{29}$

\section{Conclusion}

According to early literature reports, $\mathrm{VCl}_{3}$ reacts quickly with alcohols to give vanadium(IV)/(V) alkoxides leaving free chloride in solution. ${ }^{5}$ Moreover, vanadium(III) is highly oxophilic and produces stable vanadyl complexes in the presence of traces of moisture or $\mathrm{O}_{2}$. Strict dioxygen and moisture exclusion conditions are needed to avoid oxidation and hydrolysis involving the metal. The formation of the desired $\left[\mathrm{VCl}_{2}\left\{\mathrm{Ti}_{2}\left(\mathrm{OPr}^{\mathrm{i}}\right)_{9}\right\}\right]$ by the route described in this work is dependent on the preservation of the metal oxidation state and cannot be accomplished if vanadyl species are formed in the reaction mixture. Simple Schlenk line conditions give reproducible results for this preparation, but do not appear to be adequate to give the heterometallic product. Product 1 has been used as a precursor to nanosized particles of $\mathrm{TiO}_{2}$ by a sol-gel process. Details of these preparations will be described elsewhere.

\section{Acknowledgements}

We are grateful to Mrs. J. Elaine Barclay (John Innes Centre, Norwich, UK) for NMR analysis, Prof. Ney V. Vugman (Instituto de Física, Universidade Federal do Rio de Janeiro) and Geraldo R. Friedermann (Departamento de Química, UFPR) for the help with the EPR spectra, Prof. Elisabeth de Oliveira (USP) and Mr. Osnildo de Oliveira (LACTEC) for metal analyses. This work has been supported by the Brazilian PRONEX Program (contract number 41.96.0884.00), Brazilian Research Council (CNPq), Coordenação de Aperfeiçoamento de Pessoal de Nível Superior (CAPES), Fundação Araucária and Universidade Federal do Paraná (UFPR).

\section{Supplementary Information}

Crystallographic data (excluding structure factors) have been deposited with the Cambridge Crystallographic Data Centre (CCDC) as supplementary material. Copies can be obtained from the CCDC, 12 Union Road, Cambridge CB2 1EZ, UK (fax: +44 1223336033 or email: deposit@ccdc.cam.ac.uk), quoting the deposition numbers CCDC 205651 (complex 1) and 205594 (complex 2).

\section{References}

1. Nunes, G.G.; Reis, D. M.; Amorim, P. T.; Sá, E. L.; Mangrich, A. S.; Evans, D. J.; Hitchcock, P. B.; Leigh, G. J.; Nunes, F. S.; Soares, J. F.; New J. Chem. 2002, 26, 519; Nunes, G.G.; Friedermann, G. R.; Herbst, M. H.; Barthem, R. B.; Vugman, N. V.; Barclay, J. E.; Evans, D. J.; Hitchcock, P. B.; Leigh, G. J.; Sá, E. L.; Soares, J. F.; Inorg. Chem. Commun. 2003, 6, 1278.

2. Denisov, N. T.; Shuvalova, N. I.; Shilov, A. E.; Kinet. Catal. 1994, 35, 700; Dzhabiev, T. S.; Mironova, M. A.; Shilov, A. E.; Kinet. Catal. 1999, 40, 764; Bazhenova, T. A.; Shilov, A. E.; Coord. Chem. Rev. 1995, 144, 69 and references therein.

3. Schrauzer, G. N.; Guth, T. D.; J. Am. Chem. Soc. 1977, 99, 7189; Edwards, J. G.; Davies, J. A.; Boucher, D. L.; Mennad, A.; Angew. Chem., Int. Ed. Engl. 1992, 31, 480; Davies, J. A.; Edwards, J. G.; Angew. Chem., Int. Ed. Engl. 1993, 32, 552.

4. Hughes, D. L.; Larkworthy, L. F.; Leigh, G. J.; McGarry, C. J.; Sanders, J. R.; Smith, G. W.; deSouza, J. S.; J. Chem. Soc., Chem. Commun. 1994, 2137; Leigh, G. J.; deSouza, J. S.; Coord. Chem. Rev. 1996, 154, 71; Hitchcock, P. B.; Hughes, D. L.; Larkworthy, L. F.; Leigh, G. J.; Marmion, C. J.; Sanders, J. R.; Smith, G. W.; deSouza, J. S.; J. Chem. Soc., Dalton Trans. 1997, 1127; Davies, S. C.; Hughes, D. L.; Leigh, G. J.; Sanders, J. R.; deSouza, J. S.; J. Chem. Soc., Dalton Trans. 1997, 1981; Evans, D. J.; Hitchcock, P. B.; Leigh, G. J.; Nicholson, B. K.; Niedwieski, A. C.; Nunes, F. S.; Soares, J. F.; Inorg. Chim. Acta, 2001, 319, 147.

5. Bradley, D. C.; Mehta, M. L.; Can. J. Chem. 1962, 40, 1710; Razuvaev, G. A.; Vyshinskaya, L. I.; Drobotenko, V. V.; Mal'Kova, G. Ya.; Vyshinsky, N. N.; J. Organomet. Chem. 1982, 239, 335.

6. Bradley, D. C.; Multani, R. K.; Wardlaw, W.; J. Chem. Soc. 1958, 936

7. Bradley, D. C.; Mehta, M. L.; Can. J. Chem. 1962, 40, 1183; Haaland, A.; Rypdal, K.; Volden, H. V.; Andersen, R. A.; J. Chem. Soc., Dalton Trans. 1992, 891.

8. Salta, J.; Zubieta, J.; Inorg. Chim. Acta, 1997, 257, 83.

9. Perrin, D. D.; Armarego, W. L. F.; Purification of Laboratory Chemicals, $3^{\text {rd }}$ ed., Butterworth Heinemann: Oxford, 1997.

10. O’Connor, C. J.; Prog. Inorg. Chem. 1982, 29, 203.

11. Hampdem-Smith, M. J.; Williams, D. S.; Rheingold, A. L.; Inorg. Chem. 1990, 29, 4076.

12. Bradley, D. C.; Mehrotra, R. C.; Swanwick, J. D.; Wardlaw, W.; J. Chem. Soc. 1953, 2025.

13. Moran, P. D.; Bowmaker, G. A.; Cooney, R. P.; Inorg. Chem. 1998, 37, 2741.

14. Farrugia, L. J.; J. Appl. Crystallogr. 1999, 32, 837.

15. Sheldrich, G. M.; SHELXL-97: Program for Crystal Structure Refinement, University of Gottingen, Germany, 1997. 
16. Ridley, J. E.; Zerner, M. C.; Theoret. Chim. Acta (Berlin) 1973, 32, 111; Bacon, A. D.; Zerner, M. C.; Theoret. Chim. Acta (Berlin) 1979, 53, 21; Zerner, M. C.; Loew, G. H.; Kirchner, R. F.; Mueller-Westerhoff, U. T.; J. Am. Chem. Soc. 1980, 102, 589; Anderson, W. P.; Edwards, W. D.; Zerner, M. C.; Inorg. Chem. 1986, 25, 2728; Anderson, W. P.; Cundari, T. R.; Drago, R. S.; Zerner, M. C.; Inorg. Chem. 1990, 29, 1; Anderson, W. P.; Cundari, T. R.; Zerner, M. C.; Int. J. Quantum Chem. 1991, 39, 31; Cory, M. G.; Kostlmeyer, S.; Kotzian, M.; Rosch, N.; Zerner, M. C.; J. Chem. Phys. 1994, 100, 1353; Stavrev, K. K.; Zerner, M. C.; Chem. Phys. Lett. 1996, 263, 667; O’Brien, T. A.; Albert, K.; Zerner, M. C., J. Chem. Phys. 2000, 112, 3192.

17. Kotani, M.; Amemiya, A.; Ishiguro, E.; Kimura, T.; Table of Molecular Integrals, Maruzen Co.: Tokyo, 1955; Preuss, H.; Integraltafeln zur Quantenchemie, Springer-Verlag: Berlin, 1956.

18. http://www.planaria-software.com, acessed in 23/09/2003.

19. Mataga, N.; Nishimoto, K.; Zeit. Physik. Chem. (Frankfurt) 1957, 12, 335; Mataga, N.; Nishimoto, K.; Zeit. Physik. Chem. (Frankfurt) 1957, 13, 140.

20. Barraclough, C. G.; Bradley, D. C.; Lewis, J.; Thomas, I. M.; J. Chem. Soc. 1961, 2601.
21. Winter, C. H.; Sheridan, P. H.; Heeg, M. J.; Inorg. Chem. 1991, 30, 1962.

22. Schubert, U.; Neugebauer, D.; Scharf, W. J.; J. Organomet. Chem. Commun. 1981, 205, 159; Erker, G.; Engel, K., Atwood, J. L.; Hunter, W. E.; Angew. Chem. Int. Ed. Engl. 1983, 22, 494; Tikkanen, W. R.; Petersen, J. L.; Organometallics, 1984, 3, 1651; Gambarotta, S.; Strologo, S.; Floriani, C.; ChiesiVilla, A.; Guastini, C.; Inorg. Chem. 1985, 24, 1651.

23. Caulton, K. G.; Hubert-Pfalzgraf, L. G.; Chem. Rev. 1990, 90 , 969.

24. Wu, Y. T.; Ho, Y. C.; Lin, C. C.; Gau, H. M.; Inorg. Chem. 1996, 35, 5948; Winter, C. H.; Sheridan, P. H.; Heeg, M. J.; Inorg. Chem. 1991, 30, 1962.

25. Ceccato, A. S.; Neves, A.; de Brito, M. A.; Drechsel, S. M.; Mangrich, A. S.; Werner, R.; Haase, W.; Bortoluzzi, A. J.; J. Chem. Soc., Dalton Trans. 2000, 1573.

26. Priebsch, W.; Rehder, D.; Inorg. Chem. 1990, 29, 3013.

27. Goodman, B. A.; Raynor, J. B.; J. Inorg. Nucl. Chem. 1970, $32,3406$.

28. Zah-Letho, J.; Samuel, E.; Livage, J.; Inorg. Chem. 1988, 27 , 2233.

29. Mabbs, F. E.; Chem. Soc. Rev. 1993, 22, 313.

Received: March 6, 2003

Published on the web: October 9, 2003 